\title{
Correlation among Shell Percent, Cocoon Yield and Reeling Parameters of Multi x Bi Cocoons under Different Agro-Climatic Conditions of West Bengal, India
}

\author{
Subhra Chanda, Lal Mohan Saha*, Nirvan Kumar Das, Niharendu Bikash Kar, and Bharat Bhusan \\ Bindroo
}

Central Sericultural Research \& Training Institute, Berhampore, West Bengal, 742 101, India

\section{Abstract}

Three new Multi x Bi combinations M.Con.4 x (SK6 x SK7), M.Con.4 x NB4D2 and Nistari $x\left(\right.$ SK6 $x$ SK7) were studied in five seasons i.e. during the period of $18^{\text {th }} \mathrm{June}-12^{\text {th }} \mathrm{July}, 30^{\text {th }}$ August $-23^{\text {rd }}$ September, $3^{\text {rd }}$ November $-2^{\text {nd }}$ December, $29^{\text {th }}$ January- $2^{\text {nd }}$ March and $30^{\text {th }}$ March-25 $5^{\text {th }}$ April with one control Nistari $x$ NB4D2 considering nine reeling characteristics along with shell percent and cocoon yield per 100 disease free layings (DFLs) to establish the seasonal effect on all the parameters. Results reveal that all the characters performed well in November-December. Highest yield per 100 DFLs was recorded during NovemberDecember in all combinations showing $>60 \mathrm{~kg}$ yield. Higher correlation of yield/100 DFLs with filament length, non-breakable filament length, denier, raw silk percent, reelability percent and recovery percent was recorded in all combinations of Multi $x \mathrm{Bi}$ considered in this study. Variability observed among four combinations indicates the effect of different temperature and humidity of different seasons on expression of different traits. The results indicate that there is significant relationship of raw silk percent with reelability percent, recovery percent and evenness. Reelability percent showed higher correlation with recovery percent. It was observed that neatness was positively correlated with evenness. The overall performance of the newly evolved combinations with regard to productivity and reeling characteristics is discussed emphasizing their utilization at commercial level.

Received : 2 May 2013

Accepted : 20 June 2013

Keywords:

Combination,

Shell percent,

Sustainable productivity,

Disease free layings,

Correlation

\section{Introduction}

Genesis of quality and quantity of mulberry silkworm cocoons is a challenge for West Bengal - a state of tropical atmosphere. Quality and quantity of silk produced by Multivoltine x Bivoltine silkworms is better than the silk produced by Multivoltine x Multivoltine silkworms. Adoption of Multi x Bi rearing by the farmers of West Bengal is an approach to meet the challenge. Breeders are engaged in search of season specific suitable breeds/hybrids aiming to provide sustainable productivity at field level. Some Multi x Bi hybrids have already won popularity among farmers. From the commercial point of view yield of cocoons per 100 DFLs and shell

\section{*Corresponding Author :}

Lal Mohan Saha

Central Sericultural Research \& Training Institute, Berhampore, West Bengal, 742 101, India.

Tel: +91-9474848648 / FAX: +91-3482224689

E-mail: saha.lalmohan@rediffmail.com

C 2013 The Korean Society of Sericultural Sciences 
percent hold the crucial role. Silk - produced by reeling of cocoons is the main commercial parameter (Reddy et al., 2010). Reeling characters viz. Filament lengths (FL), Non-breakable Filament length (NBFL), Denier (D), Renditta i.e.quantity of green cocoon is required to produce $1 \mathrm{~kg}$ silk yearn, Reelability percent, and Raw Silk percent are the main quantitative parameters and quality of silk depends upon neatness and evenness of the silk. Satenahalli et al. (1990) observed positive correlation among cocoon weight, shell weight, shell ratio and FL. According to Ohi and Yamashita (1977), the characters viz. FL, cocoon shape and shell percent are highly heritable. West Bengal experiences wide range of fluctuation in temperature, humidity and precipitation rate (Moorthy and Das, 2007; Moorthy et al., 2011). Highly variable climatic condition in different seasons has its impact on the commercial characters related to production. Higher correlation among cocoon weight, shell weight and co-heritability with silk yield was established by Siddiqui et al., (1989) and Naqvi et al., (2004). Present study is an attempt to find out the possible inter-relationship between the productivity and reeling parameters of Multi $\mathrm{x} B \mathrm{Bi}$ cocoons under varied agro-climatic conditions of W.B., India.

\section{Materials and Methods}

\section{Test materials}

Two multivoltine breeds M.Con.4 and Nistari and two bivoltine breeds (SK6 x SK7) and NB4D2 were selected for this study and the experiment was conducted at the Silkworm Breeding and Genetics Section, Central Sericultural Research and Training Institute, Berhampore, West Bengal. Cocoons produced by 3 Multi x Bi hybrids viz. M.Con.4 x (SK6 x SK7), M.Con.4 x NB4D2 and Nistari $x$ (SK6 $x$ SK7) were considered as test materials against the traditional Multi $x$ Bi combination Nistari $x$ NB4D2 - the control.

\section{Rearing and Reeling procedure}

Three replications@ @ 400 worms per replication after $3^{\text {rd }}$ moult per combination were maintained throughout the rearing period after $3^{\text {rd }}$ moult. Twenty five good cocoons from each replication of each combination were assessed for cocoon weight, shell weight, and shell percent. For assessment of reeling parameters $300 \mathrm{~g}$ of green cocoons from each replication of each combination were dried in hot oven. The drying chamber was heated upto $120^{\circ} \mathrm{C}$. The cocoons were then put into drying chamber to remove moisture mixed with the air inside the cocoon at faster rate, so that inner layer sericin is not affected. The cocoons were subjected to drying schedule of $115^{\circ} \mathrm{C}$ (one hour) $\rightarrow 100^{\circ} \mathrm{C}$ (one hour) $\rightarrow 85^{\circ} \mathrm{C}$ (one hour) $\rightarrow 70^{\circ} \mathrm{C}$ (one hour) $\rightarrow 55^{\circ} \mathrm{C}$ (one hour). Hot air dried cocoons were conditioned for a minimum period of 2 to 7 days in atmospheric conditions. The length of the filament was measured using epprovette fitted with meter. Other reeling parameters were studied following standard procedures.

\section{Correlation study}

Correlation among shell percent, cocoon yield per 100 DFLs and nine reeling parameters viz. FL, NBFL, denier, renditta, reelability percent, raw silk percent, neatness and evenness were estimated as per standard procedures.

\section{Statistical analysis}

Analysis of variance was applied for each character for above mentioned five seasons

\section{Results}

\section{Temperature and humidity}

Data in Table 1 shows the average temperature and humidity

Table 1. Season wise temperature and humidity of the rearing room

\begin{tabular}{|ccccc|}
\hline \multirow{2}{*}{ Season } & \multicolumn{2}{c}{ Temperature } & \multicolumn{2}{c|}{ Humidity } \\
\cline { 2 - 5 } & \multicolumn{2}{c}{$\left.{ }^{\circ} \mathrm{C}\right)$} & \multicolumn{2}{c|}{$(\%)$} \\
\hline Max. & Min. & Max. & Min. \\
\hline June - July & 31 & 24 & 86 & 65 \\
\hline Nugust - September, & 31 & 27 & 86 & 73 \\
\hline January - March & 26 & 19 & 80 & 65 \\
\hline March - April & 31 & 25 & 87 & 70 \\
\hline
\end{tabular}


of the rearing room in different seasons. Highest temperature and humidity was observed during the period $30^{\text {th }}$ August $-23^{\text {rd }}$ September. Suitable temperature and humidity for silkworm rearing was observed during the season November - December.

\section{Seasonal influence on productivity and reeling performance}

Effect of temperature and humidity prevailed in different

Table 2. Impact of different seasons on shell percent, yield / 100 DFLs and reeling parameters

\begin{tabular}{|c|c|c|c|c|c|c|c|}
\hline Season & Combination & $\begin{array}{l}\text { Shell } \\
(\%)\end{array}$ & $\begin{array}{l}\text { Yield/ } 100 \\
\text { DFLs (kg) }\end{array}$ & $\begin{array}{l}\text { FL } \\
(m)\end{array}$ & $\begin{array}{l}\text { NBFL } \\
(\mathrm{m})\end{array}$ & Denier & $\begin{array}{c}\text { Ren-ditta } \\
\text { (kg) }\end{array}$ \\
\hline \multirow{6}{*}{ June - July } & M.Con. 4 x (SK6 x SK7) & 19.28 & 33.556 & 677 & 540 & 2.39 & 10.42 \\
\hline & Nistari x (SK6 x SK7) & 18.46 & 35.111 & 704 & 704 & 2.61 & 9.68 \\
\hline & M.Con.4 x NB4D2 & 18.94 & 33.111 & 639 & 590 & 2.16 & 9.68 \\
\hline & Nistari x NB4D2 & 17.99 & 34.044 & 692 & 561 & 2.19 & 11.63 \\
\hline & CD at $5 \%$ & NS & NS & 28 & 24 & 0.16 & 0.30 \\
\hline & CV\% & 2.93 & 4.30 & 2.17 & 2.10 & 3.68 & 1.51 \\
\hline \multirow{6}{*}{$\begin{array}{l}\text { August - } \\
\text { September }\end{array}$} & M.Con.4 x (SK6 x SK7) & 18.56 & 47.911 & 759 & 586 & 2.36 & 10.08 \\
\hline & Nistari x (SK6 x SK7) & 18.17 & 50.089 & 747 & 637 & 2.44 & 8.47 \\
\hline & M.Con.4 x NB4D2 & 20.64 & 50.711 & 643 & 551 & 2.47 & 9.34 \\
\hline & Nistari x NB4D2 & 17.61 & 52.622 & 766 & 652 & 2.30 & 8.58 \\
\hline & $\mathrm{CD}$ at $5 \%$ & 1.51 & 1.29 & 84 & NS & NS & NS \\
\hline & CV\% & 4.28 & 1.36 & 6.11 & 8.70 & 3.12 & 9.58 \\
\hline \multirow{6}{*}{$\begin{array}{l}\text { November - } \\
\text { December }\end{array}$} & M.Con.4 x (SK6 x SK7) & 16.58 & 64.800 & 811 & 808 & 2.44 & 9.21 \\
\hline & Nistari x (SK6 x SK7) & 16.56 & 66.667 & 705 & 695 & 2.48 & 9.77 \\
\hline & M.Con.4 x NB4D2 & 16.42 & 66.356 & 783 & 783 & 2.61 & 8.59 \\
\hline & Nistari x NB4D2 & 17.48 & 66.222 & 661 & 661 & 2.82 & 9.22 \\
\hline & CD at $5 \%$ & NS & NS & 52 & 53 & 0.13 & NS \\
\hline & CV\% & 5.82 & 3.63 & 3.75 & 3.84 & 2.65 & 5.01 \\
\hline \multirow{6}{*}{ January - March } & M.Con.4 x (SK6 x SK7) & 17.53 & 60.489 & 690 & 653 & 2.57 & 9.96 \\
\hline & Nistari x (SK6 x SK7) & 16.38 & 57.311 & 687 & 562 & 2.56 & 10.45 \\
\hline & M.Con.4 x NB4D2 & 19.06 & 59.556 & 699 & 699 & 2.48 & 9.42 \\
\hline & Nistari x NB4D2 & 17.11 & 55.778 & 661 & 661 & 2.48 & 9.63 \\
\hline & $\mathrm{CD}$ at $5 \%$ & 1.23 & 2.68 & NS & NS & NS & 0.48 \\
\hline & CV\% & 3.73 & 2.44 & 6.05 & 8.29 & 3.07 & 2.56 \\
\hline \multirow{6}{*}{ March - April } & M.Con.4 x (SK6 x SK7) & 18.17 & 42.045 & 699 & 599 & 2.29 & 10.22 \\
\hline & Nistari x (SK6 x SK7) & 16.86 & 43.200 & 697 & 592 & 2.59 & 9.31 \\
\hline & M.Con.4 x NB4D2 & 18.89 & 44.267 & 694 & 685 & 2.46 & 9.58 \\
\hline & Nistari x NB4D2 & 18.06 & 54.044 & 691 & 598 & 2.29 & 10.42 \\
\hline & CD at $5 \%$ & 0.85 & 5.21 & NS & NS & 0.20 & NS \\
\hline & CV\% & 2.49 & 6.03 & 5.94 & 6.31 & 4.42 & 9.10 \\
\hline
\end{tabular}


Table 2. (continued)

\begin{tabular}{|c|c|c|c|c|c|c|}
\hline Season & Combination & $\begin{array}{c}\text { Raw silk } \\
(\%)\end{array}$ & $\begin{array}{c}\text { Reelability } \\
(\%)\end{array}$ & $\begin{array}{c}\text { Recovery } \\
(\%)\end{array}$ & $\begin{array}{c}\text { Neatness } \\
(\%)\end{array}$ & $\begin{array}{c}\text { Evenness } \\
(\%)\end{array}$ \\
\hline \multirow{6}{*}{ June - July } & M.Con.4 x (SK6 x SK7) & 9.59 & 62.48 & 80.00 & 81.25 & 86.25 \\
\hline & Nistari x (SK6 x SK7) & 10.33 & 65.29 & 81.81 & 85.00 & 90.00 \\
\hline & M.Con.4 x NB4D2 & 10.33 & 64.46 & 81.25 & 87.50 & 91.25 \\
\hline & Nistari x NB4D2 & 8.59 & 63.17 & 79.31 & 85.00 & 90.00 \\
\hline & CD at $5 \%$ & 0.25 & 0.57 & NS & 0.46 & 1.07 \\
\hline & CV\% & 1.38 & 0.47 & 1.26 & 0.29 & 0.64 \\
\hline \multirow{6}{*}{$\begin{array}{l}\text { August - } \\
\text { September }\end{array}$} & M.Con.4 x (SK6 x SK7) & 10.10 & 66.31 & 81.68 & 88.75 & 90.83 \\
\hline & Nistari x (SK6 x SK7) & 11.81 & 79.70 & 83.38 & 87.08 & 92.08 \\
\hline & M.Con.4 x NB4D2 & 10.75 & 68.32 & 81.70 & 90.00 & 95.00 \\
\hline & Nistari x NB4D2 & 11.66 & 78.57 & 85.12 & 85.83 & 94.17 \\
\hline & CD at $5 \%$ & NS & 7.69 & 1.83 & NS & NS \\
\hline & CV\% & 8.61 & 5.58 & 1.17 & 2.56 & 2.93 \\
\hline \multirow{6}{*}{$\begin{array}{l}\text { November - } \\
\text { December }\end{array}$} & M.Con.4 x (SK6 x SK7) & 10.70 & 79.33 & 83.67 & 85.83 & 90.83 \\
\hline & Nistari x (SK6 x SK7) & 10.27 & 80.66 & 85.10 & 87.50 & 92.50 \\
\hline & M.Con.4 x NB4D2 & 11.67 & 82.43 & 85.43 & 84.14 & 89.14 \\
\hline & Nistari x NB4D2 & 10.85 & 80.99 & 85.31 & 82.92 & 87.92 \\
\hline & CD at $5 \%$ & NS & NS & NS & 2.55 & 2.55 \\
\hline & CV\% & 5.34 & 1.45 & 1.98 & 1.59 & 1.50 \\
\hline \multirow{6}{*}{ January- March } & M.Con.4 x (SK6 x SK7) & 10.04 & 83.07 & 83.01 & 85.83 & 90.83 \\
\hline & Nistari x (SK6 x SK7) & 9.57 & 80.24 & 81.19 & 85.83 & 90.83 \\
\hline & M.Con.4 x NB4D2 & 10.62 & 83.14 & 82.70 & 85.00 & 87.83 \\
\hline & Nistari x NB4D2 & 10.39 & 79.27 & 82.84 & 85.00 & 90.00 \\
\hline & CD at $5 \%$ & 0.50 & 1.84 & NS & NS & NS \\
\hline & CV\% & 2.60 & 1.20 & 1.81 & 2.80 & 2.51 \\
\hline \multirow{6}{*}{ March-April } & M.Con.4 x (SK6 x SK7) & 9.79 & 75.73 & 80.42 & 87.08 & 92.08 \\
\hline & Nistari x (SK6 x SK7) & 10.75 & 74.19 & 80.41 & 80.83 & 87.92 \\
\hline & M.Con.4 x NB4D2 & 10.53 & 71.40 & 81.15 & 87.50 & 92.92 \\
\hline & Nistari x NB4D2 & 9.69 & 68.52 & 80.43 & 88.75 & 93.75 \\
\hline & CD at $5 \%$ & NS & 2.25 & NS & 2.25 & 1.66 \\
\hline & CV\% & 8.45 & 1.65 & 2.37 & 1.39 & 0.96 \\
\hline
\end{tabular}

seasons on the productivity and reeling performance has been given in Table 2. Analysis of results reveal that all combinations of Multi x Bi performed better during the season NovemberDecember concerning yield per 100 DFLs ranging from 64.8 $\mathrm{kg}$ in M.Con.4 x (SK6 x SK7) to $66.667 \mathrm{~kg}$ in Nistari x (SK6 $x$ SK7) without showing any significant difference among the combinations. Performance of filament length ranged from 661 $\mathrm{m}$ in Nistari $\mathrm{x}$ NB4D2 to $811 \mathrm{~m}$ in M.Con.4 $\mathrm{x}$ (SK6 x SK7) and 
Table 3. Correlation among different traits of four combinations of silkworm, Bombyx mori

\begin{tabular}{|c|c|c|c|c|c|c|c|c|c|c|}
\hline & $\begin{array}{l}\text { Yield/100 } \\
\text { DFLs(kg) }\end{array}$ & FL (m) & $\begin{array}{l}\text { NBFL } \\
(\mathrm{m})\end{array}$ & Denier & $\begin{array}{c}\text { Renditta } \\
\text { (kg) }\end{array}$ & $\begin{array}{c}\text { Raw } \\
\text { silk (\%) }\end{array}$ & $\begin{array}{c}\text { Reelability } \\
(\%)\end{array}$ & $\begin{array}{c}\text { Recovery } \\
(\%)\end{array}$ & $\begin{array}{c}\text { Neatness } \\
(\%)\end{array}$ & $\begin{array}{c}\text { Evenness } \\
(\%)\end{array}$ \\
\hline Shell (\%) & $-0.482^{\star *}$ & $-0.262^{\star *}$ & $-0.312^{\star *}$ & $-0.265^{\star *}$ & $0.113^{\star *}$ & $-0.109^{*}$ & $-0.506^{* *}$ & $-0.362^{* *}$ & $0.241^{* *}$ & $0.116^{* *}$ \\
\hline $\begin{array}{l}\text { Yield/100 } \\
\text { DFLs(kg) }\end{array}$ & & $0.283^{* *}$ & $0.509^{* *}$ & $0.485^{\star *}$ & $-0.363^{\star *}$ & $0.351^{* *}$ & $0.813^{* *}$ & $0.650^{* *}$ & 0.070 & 0.068 \\
\hline $\mathrm{FL}(\mathrm{m})$ & & & $0.645^{\star *}$ & -0.039 & $-0.180^{* *}$ & $0.190^{* *}$ & $0.201^{\star *}$ & $0.229^{* *}$ & -0.034 & $0.088^{*}$ \\
\hline $\operatorname{NBFL}(\mathrm{m})$ & & & & $0.287^{* *}$ & $-0.291^{* *}$ & $0.257^{* *}$ & $0.461^{* *}$ & $0.442^{* *}$ & $-0.135^{\star *}$ & -0.075 \\
\hline Denier & & & & & $-0.352^{* *}$ & $0.338^{* *}$ & $0.462^{* *}$ & $0.345^{\star *}$ & $-0.317^{* *}$ & $-0.231^{* *}$ \\
\hline Renditta (kg) & & & & & & $-0.986^{\star *}$ & $-0.421^{* *}$ & $-0.625^{\star *}$ & 0.008 & $-0.157^{* *}$ \\
\hline Raw silk (\%) & & & & & & & $0.398^{* *}$ & $0.632^{* *}$ & 0.005 & $0.188^{* *}$ \\
\hline Reelability (\%) & & & & & & & & $0.581^{* *}$ & -0.083 & $-0.086^{*}$ \\
\hline Recovery (\%) & & & & & & & & & 0.007 & 0.080 \\
\hline Neatness (\%) & & & & & & & & & & $0.732^{* *}$ \\
\hline
\end{tabular}

**Significant at $1 \%$ level, *significant at $5 \%$ level.

NBFL ranged from $661 \mathrm{~m}$ in Nistari $x$ NB4D2 to 808 in M.Con.4 x (SK6 x SK7). Renditta i.e. requirement of green cocoon to obtain $1 \mathrm{~kg}$ silk yearn, raw silk percent, reelability percent and recovery percent showed better performance in M.Con.4 x NB4D2 $8.59 \mathrm{~kg}$, $11.67 \%, 82.43 \%$ and $85.43 \%$ respectively. No significant difference was recorded among other combinations for these four economically important characters. Significantly higher performance $(\mathrm{P}<0.05)$ concerning neatness and evenness was noted in M.Con.4 x (SK6 x SK7) (85.83\% and 90.83\% respectively) and Nistari x (SK6 x SK7) $(87.50 \%$ and $92.50 \%$ respectively). No significant result was obtained in shell percent during the season November-December. Among five seasons lowest shell percent was observed during November-December, ranging from $16.42 \%$ in M.Con. 4 x NB4D2 to $17.48 \%$ in Nistari $x$ NB4D2.

Highest shell percent was recorded during the rearing season August-September in M.Con.4 x NB4D2 (20.64\%) followed by $19.28 \%$ during Shravani in M.Con.4 x (SK6 x SK7), 19.06\% in M.Con.4 x NB4D2 in Falgooni and $18.89 \%$ in Baisakhi in M.Con. 4 x NB4D2.

Lowest yield per 100 DFLs was observed in all combinations during the season June-July, ranging from $33.111 \mathrm{~kg}$ in M.Con.4 $x$ NB4D2 to $35.111 \mathrm{~kg}$ in Nistari $x$ (SK6 x SK7) without showing any significant difference among yield. During the season highest renditta $(11.63 \mathrm{~kg})$ was observed in Nistari $\mathrm{x}$ NB4D2.
In all seasons recovery percent, neatness and evenness showed $>80 \%$ result in all combinations.

\section{Impact of seasons on reeling performance}

Reelability percent was lowest in the season June-July for all combinations ranging from $62.48 \%$ in M.Con. 4 x (SK6 x SK7) to $65.29 \%$ in Nistari $x$ (SK6 x SK7) followed by the seaso AugustSeptember ranging from $66.31 \%$ in M.Con.4 x (SK6 x SK7) to $79.70 \%$ in Nistari x (SK6 x SK7), In March-April season it was ranging from $68.52 \%$ in Nistari $x$ NB4D2 to $75.73 \%$ in M.Con.4 $x(\mathrm{SK} 6 \times \mathrm{SK} 7)$, it was 79.33\% in M.Con.4 x (SK6 x SK7) to $82.43 \%$ in M.Con. 4 x NB4D2 in November- December season and it was from $79.27 \%$ in Nistari x NB4D2 to $83.14 \%$ in M.Con.4 $x$ NB4D2 during the rearing season January-March.

Comparatively finest denier was observed during June-July in M.Con.4 x NB4D2 (2.16) and Nistari x NB4D2 (2.19) followed by 2.39 in M.Con.4 x (SK6 x SK7) and 2.61 in Nistari x (SK6 x SK7).

Raw silk percent was highest $(10.70 \%)$ during NovemberDecember in M.Con.4 x (SK6 x SK7). In Nistari x (SK6 x SK7) highest raw silk percent (11.81\%) was observed in AugustSeptember, in M.Con.4 x NB4D2 highest raw silk percent (11.67\%) was observed during November- December and in Nistari x NB4D2 highest raw silk percent (11.66\%) was recorded during August-September season. 


\section{Correlation among different parameters}

Studies on correlation (Table 3) among shell percent yield per 100 DFLs and reeling parameters indicate the positive correlation of shell percent with renditta, neatness and evenness. Yield per 100 DFLs was highly correlated with FL, NBFL, denier, raw silk percent, reelability percent and recovery percent. Positive correlation of FL was recorded with NBFL, raw silk percent, reelability percent, recovery percent and evenness. NBFL showed positive correlation with denier, raw silk percent, reelability percent and recovery percent. Denier had positive correlation with raw silk percent, reelability percent and recovery percent. Significantly higher negative correlation of renditta was observed with raw silk percent, reelability percent, recovery percent and evenness. Positive correlation of raw silk percent was observed with reelability percent, recovery percent and evenness. Reelability percent was highly correlated with recovery percent. It was observed that neatness was positively correlated with evenness.

\section{Discussion}

Concerning productivity and reeling parameters, better performance of all Multi x Bi combinations in NovemberDecember season is attributed to the fact that the temperature and humidity maintained in the rearing room in this season is ideal for better performance. Highest filament length was observed in the period in M.Con.4 x (SK6 x SK7) establishes the superiority of this combination in respect of the most important economic trait related with the productivity of the hybrid (Chattopadhyay et al., 2001; Dayananda et al., 2011). Highest shell percent in the hybrids utilizing M.Con.4 as female component indicate the efficiency of the breed in conversion of leaf to silk compared to the females of Nistari. Quality of raw silk depends upon the ideal temperature and humidity coupled with good quality of leaf. During NovemberDecember growth of leaf retards which affect the quantity of cocoons (Gowda and Reddy, 2007). Lowest yield/100 DFLs and reeling performance during June-July was resulted for high temperature and high humidity. This is in agreement with Gowda and Reddy (2006). Low reeling performance in June-July season and in August-September is attributed to the structural changes in the sericin for moisture content in the cocoon layer during spinning stage (Akahane and Tsubouchi, 1994; Naik and Somashekar,
2008). It is also in agreement with Kamatsu (1975) that humidity has an adverse effect on reelability of cocoon compared to the seasons with high temperature by reducing the solubility of sericin and cocoon quality of same combination shows variability in different seasons. In the quality parameters of raw silk i.e. in neatness and evenness percent performance of $>80 \%$ in all seasons among all combinations indicate the systematic maintenance of microclimatic condition of the rearing and spinning room. Lower shell percent during November-December confirms the findings of Nakada (1972) that females of the hybrids grow too quickly which has an adverse effect on the cocoon shell weight. Finest denier was recorded in June-July in the combinations utilizing NB4D2 as a male component over the combinations using (SK6 x SK7) as a male component emphasizing on the need for season specific breed as donor. Highest raw silk percent of M.Con.4 x (SK6 x SK7) and M.Con.4 x NB4D2 during November-December and highest raw silk percent of Nistari x (SK6 x SK7) and Nistari $x$ NB4D2 in August-September establish the species specificity in conversion of leaf to reelable silk in different seasons.

Variation in reelability is according to specific breed, rearing seasons and the cocoon produced by male/female. Due to high temperature it is reported that sericin degenerates and the reelability and raw silk percent declines.

Less variation in denier among different combinations in different seasons reveals less impact of the season on evenness character of the resultant raw silk thread. Shell percent of silkworm and the yield/100 DFLs are the most important characters and are directly related with the production of silk. Po sitive correlation of shell percent with renditta observed by Sonwalkar (2001) has also been recorded in this study.

Better quality of silk produced by Multi x $\mathrm{Bi}$ is ascertained from the positive correlation of shell percent with neatness and evenness. Higher raw silk percent establishes better neatness character of the filament of the silkworm combinations considered for this study. Positive correlation between yield/100 DFLs and filament length recorded in this study is agreed with the observation of Sekharappa et al. (1999). Higher correlation of yield per100 DFLs with FL, NBFL, denier, raw silk, reelability and recovery percent signifies the fact that productivity depends upon the cumulative effect of all the quantitative characters.

High correlation of yield per 100 DFLs with reelability and recovery percent confirm that quality characteristics of the cocoons develop during the growth phase of the silkworm 
and need extreme care as cocoon quality contributes to the tune of about $80 \%$ of the raw silk quality (Shimazaki, 1964; Nagadevara, 2004). High negative correlation of renditta with raw silk percent and recovery percent strengthen the view that these variables vary in the contrary direction. High correlation of raw silk percent and recovery percent imply that better the recovery of silk from cocoon better the percent of raw silk. It is also confirmed that better recovery of silk is resulted from better reelability. High correlation of neatness with evenness substantiate the better quality of silk produced by the hybrids.

Higher cocoon yield, reeling and raw silk percent with better silk quality in neatness and evenness recorded in M.Con.4 $\mathrm{x}$ (SK6 x SK7) followed by M.Con.4 x NB4D2 and Nistari x (SK6 $\times$ SK7) recommend these combinations to be utilized at commercial level to increase productivity of quality silk.

\section{Acknowledgement}

Authors are grateful to all of the co-workers of Eri Cell and Reeling and Spinning Section, Central Sericultural Research and Training Institute, Berhampore, West Bengal for their cooperation throughout the study.

\section{References}

Akahane T, Tsubouchi K (1994) Reelability and water content of cocoon layer during the spinning stage. J Seri Sci Japan 63(3), 229-234.

Chattopadhyay GK, Sengupta AK, Verma AK, Sen SK and Saratchandra B (2001) Transgression of shell weight - a multigenic trait, through development of congenic breed in tropical silkworm, Bombyx mori $\mathrm{L}$. Sericologia 41(1), 33-42.

Dayananda, Kulkarni SB, Rao PRM, Gopinath OK, Nirmal Kumar S (2011) Evaluation and selection of superior bivoltine hybrids of the silkworm Bombyx mori L. for tropics through large scale inhouse testing. Int J Plant Animal E 1(3), 16-22.

Gowda BN, Reddy NM (2006) Effect of different environmental conditions on popular multivoltine $\mathrm{x}$ bivoltine hybrids of silkworm, Bombyx mori with reference to cocoon parameters and their effect on reeling performance. Indian J Seric 45(2), 134-141.

Gowda BN, Reddy NM (2007) Influence of different environmental conditions on cocoon parameters and their effects on reeling performance of bivoltine hybrids of silkworm, Bombyx mori L. Int J Indust Entomol 14(1), 15-21.

Kamatsu K (1975) "Studies on dissolution behavior and structural characteristics of silk sericin”. Bull Seric Exp Stat Japan 26, 135-256.

Moorthy SM, Das SK (2007) Silkworm seed and commercial crops in West Bengal - Analysis. Indian Silk 46(2), 12-15.

Moorthy SM, Mandal K, Kar NB, Das SK (2011) Identification of suitable bivoltine foundation cross for sustainable bivoltine silkworm seed crop in tropics. The Bioscan 6(4), 697-700.

Nagadevara V (2004) Composite quality index of silk cocoons application of discriminant analysis. J Acad Business and Economics 4(1), 233-241.

Naik SV, Somashekar TH (2008) Influence of temperature and humidity maintained during cocoon spinning on reeling performance and quality of raw silk of Indian bivoltine hybrid cocoons. Sericologia 48(4), 379-389.

Nakada T (1972) Researches on the sex linked inheritance of cocoon weight in the silkworm, Bombyx mori L. 3.Variability of the backcrossed generation. J Fac Agric Hokkaido Univ 57, 41-50.

Naqvi AH, Srivastava AK, Sinha AK, Viswakarma SR, Roy GC (2004) Heterosis and combining ability analysis in quantitative traits of tropical tasar silkworm Antheraea mylitta D. Perspec Cytol Genet 11, 495-501.

Ohi H, Yamashita A (1977) On the breeding of the silkworm races J137 and C13. Bull Seric Exp Stn 27, 97-139.

Reddy RM, Sinha MK, Prasad BC (2010) Application of parental selection for productivity in tropical tasar silkworm, Antheraea mylitta Drury. Science Alert - Journal of Entomology 7(3), 1-15.

Satenahalli SB, Govindan R, Goud JV, Magadum SB (1990) Genetic parameters and correlation co-efficient analysis in silkworm (Bombyx mori L.). Mysore J Agric Sci 24, 491-495.

Sekharappa BM, Radhakrishna PG, Kesharareddy KS, Dandin SB (1999) Breeding of bivoltine silkworm races with better survival and high shell content for tropics-Karnataka. Sericologia 39, 205-213.

Shimazaki A (1964) Filature Technology Lecture: Published by Sericulture Association, Tokyo, 89-93.

Sonwalkar TN (2001) Hand Book of Silk Technology. pp. 14-21, New Age International(P) Limited, New Delhi.

Siddiqui AA, Sengupta AK, Dasmahapatra DP, Sengupta K (1989) Coheritability and correlation of different quantitative characters in Antheraea mylitta D. Sericologia 29, 211-214.

Sonwalkar TN (2001) Review of research works in post-cocoon harvest technology in India. Sericologia 32(1), 1-26. 